\title{
Active Deformation Measurements at Mishmi Complex of Eastern Himalayan Syntaxis
}

\author{
M. Devachandra Singh, Arun Kumar \\ Department of Earth Sciences, Manipur University, Imphal Manipur, India \\ Email: joydev55@gmail.com
}

Received April 15, 2013; revised May 16, 2013; accepted June 14, 2013

Copyright (C) 2013 M. Devachandra Singh, Arun Kumar. This is an open access article distributed under the Creative Commons Attribution License, which permits unrestricted use, distribution, and reproduction in any medium, provided the original work is properly cited.

\begin{abstract}
We focus the geodynamic status of Eastern Himalayan Syntaxis with reference to Tibetan Plateau, China and Burmese Arc using the crustal deformation constraints with GPS observation. We have used the GPS data, surface geomorphic constraints and compared the existing Pn velocity and Anisotropy [1], determined the crustal velocity of Tibetan Block and North and East China block as 2 - $8 \mathrm{~mm} / \mathrm{yr}$ and $6-11 \mathrm{~mm} / \mathrm{yr}$ considering the EHS as stable block. The lack of crustal deformation studies in EHS poses a gap in its geodynamic setup. The present attempt is first time in EHS to estimate crustal deformation by GPS. We presented GPS results from 10 stations along with one permanent station covering the EHS 2 - $3 \mathrm{~mm} / \mathrm{yr}$ with an azimuth of N460. It reveals that the EHS is moving very slow rates, which accommodates the maximum strain (after Great Earthquake of 8.7 M, Arunachal China Border 1950). The neotectonic activities are recorded along the major rivers traversing EHS follow the major thrusts and faults.
\end{abstract}

Keywords: Mishmi Complex; Eastern Himalayan Syntaxis; GPS; Crustal Deformartion

\section{Introduction}

Eastern Himalaya lies approximately 270 - 190N and 880 - 960E and has a strike of NESW with a sharp turn near 960E, where Abor Mishmi hills were formed. Near south of Mishmi hills, the Himalayas bifurcates into two partsNaga Lushai trending NE-SW and ArakanYoma belt trending NNE-SSW in the northern part. Eastern Syntaxis joins the Main Boundary Thrust (MBT) in the Himalaya with Burmese Arc (Figure 1). In the easternmost part of Arunachal Pradesh the Himalayn range abuts against the Trans Himalayan rangecommonly known as the Mishmi hills along the Tidding suture. The NW-SE trending mountain range appears to be equivalent of the Ladakh range lying to the north of the IndusTsangpo suture with a syntaxial bend. The Trans-Himalayan range can be subdivided into two parallel belts viz.one bounded by the Tidding suture to the west and the Lohit Thrust to the east and the other to the east of the Lohit Thrust. The former comprising meta sedimentaries and ultramafics, abuts against the Naga-Patkoi Range along the Mishmi Thrust and the latter, comprising the Lohit Granitoid Complex, continues to the SE as the northern Myanmar Range. The general elevation of the Trans-Himalayan Range is between $2500 \mathrm{~m}$ and 6000 m. In the last three and half decades, several scientists studied the seismotectonics of the western and eastern syntaxes to throw light on the contemporary geodynamics, crustal evolution and tectonics of the Himalaya [225]. The dominant E-Wregional trend of the Arunachal Himalaya displays an abrupt end after a sharp syntaxial bend from NE-SW in the west to NW-SE trend in the east across the Sianggorge [26-29]. The geological data on this crucial geodynamically active segment is still mostly limited to unpublished reports of the Geological Survey of India and publications by [30-34]. Appreciable neotectonic displacements have taken place along the "boundary thrusts" that define the boundaries of lithotectonic terranes and along many "tear faults" cutting the terrain transversely and obliquely [35-38]. Since the active faults are Loci of earthquakes [29,39] their identification and delineation are important in hazard-zone mapping and the management of natural hazards. The present studies also gave a broad regional framework pertaining to tectonics, relationship between active tectonic surfaces and seismicity, crustal structure and also focus on the enduring crustal evolution.

In Himalayan region, the Indian Plate underthrusts from the beginning at small angle, while at Burmese Arc system Indian plate dips at 30 - 60 and seismically very 


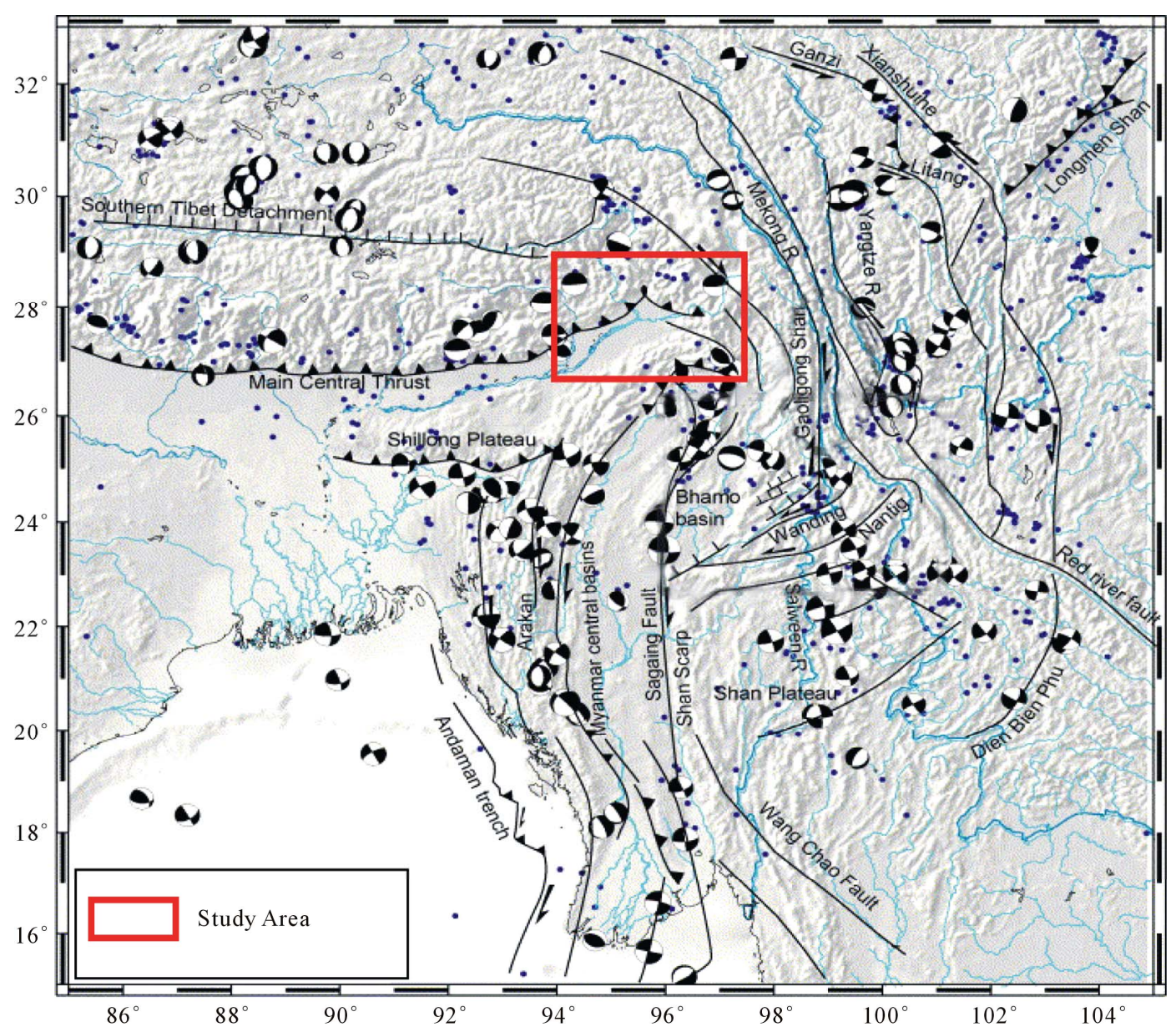

Figure 1. Seismotectonic map of NE India and adjoining regions from Tibetan Plateau, North \& South China and Burma (Modified after [54]).

active upto the depth of 150 - $200 \mathrm{kms}[16,18]$. The Eastern Himalayan Syntaxis (EHS) is a singular point of continental collision between the Indian and Eurasian plates, and has been a focus of geoscientific researches. The eastern syntaxis is a complex junction where the Indian, Eurasian and Burmese plates meet. It is here that the Indian plate is possibly being thrust under the Eurasian and Burmese plates to cause the uplift of the Eastern Him laya. The Eastern Himalayan Syntaxis, a sharp syntaxial bend, is defined by a popup antiformal structure verging towards the NE in the eastern terminal end of the Him layan arc. It is represented by two antiformal structures: a NE-SW-trending Namcha Barwaanti form with highgrade mobile rocks at core towards north and a NW-SEtrending Siang window with folded low-grade metasedimentary and meta-volcanic rocks of Abor and Miri formations in the south. The Eastern Himalayan Syntaxis is highly seismically active. The northwestern fault system produced a great earthquake at 1950 with several aftershocks. The Mishmi thrust, which borders Assam valley, is also active, but the epicentral distribution is different from those of neighbouring Himalayan and Bur- mese Arc. Eastern Syntaxis shows a clockwise rotation, North-Northeastward compression. The Assam valley, situated between Eastern Himalayas and Burmese Arc, is aseismic.

\section{Presentation Investigations}

GPS measurements have been made in campaign mode in southeast China, SE Asia covering Brunei, Indonesia, Malaysia, Philippines, Singapore, Thailand and Vietnam under the Geodynamics of South and South-East Asia (GEODYSSEA) project. Similar measurements have been made in Myanmar to infer the present-day crustal deformation around the Sagaing fault system in Central Myanmar. Since there are no GPS campaigns mode, observations from Mishmi Block occurring is poorly known.

\section{Network and GPS Measurements}

In order to carry out the crustal deformation studies of the Mishmi block a geodetic network comprising of 10 stations (Table 1) along with the permanent station has been established. The first GPS campaign measurements 
were initiated during July/August 2008 with the establishment of two stations viz. Tiwari Gaon (TWGN) and Hunli (HUNL) in the Lower Dibang Valley. Three stations in the Upper Dibang Valley viz. Rayli (RALI), Angolian (ANGO) and Amolin (AMOL). Apart from these stations two stations viz. Kamlang Nagar (KNGR) and Tidding (TDNG) were established in Lohit district. Two more stations Hayuliang (HAYU) and Wallong (WALG) were eastablished in the Anjaw district which is the innermost side of Mismi block. Above these stations the data from the Permanent GPS station (Table 2) located at Anini (ANIN), Upper Dibang Valley are used as reference. A total of 10 sites have been used to study the crustal deformation of Mishmi block. These GPS campaign stations are equipped with Leica GX1200 GPS and Leica GX500 receivers with choke ring and Zephyr geodetic antennae. All the sites selected are in the open area on the ground. All the sites are selected were:

- No obstruction above $15^{\circ}$ elevation to avoid satellite signal blockage;

- No reflecting surface (e.g. Fences, water surface);

- No nearby electrical installation.

All the sites are selected in the open area on the ground, except a few, which are located on the bed of hard rock.

\section{Monumentation}

The Monumentation normally set eventually will become unnecessary when active control networks have been established (Figure 2). Things to consider when establishing monumentation include precision and environ- ment. If high precision $(<1 \mathrm{~cm})$, repeatable results are desired, the mark itself should be $1 \mathrm{~mm}$ in diameter and the marker should be durable and stable in its medium. All markers should be resistant to weathering, but the type of marker used may be dictated by land use.

For sites located on the ground, we designed a monument in which a triangular steel plate (1.5 ft each side) is held at ground level by three twisted iron bars of lengths of about $1-1.5 \mathrm{~m}$ having a diameter of about $16 \mathrm{~mm}$. A pit is dug up to a depth of $1-2$ feet which is filled with concrete and cement till the ground level, over which the triangular steel plate is fixed.

Whereas, some campaign sites which are not suitable to construct the above monument we set up using small drilling machine. The hole about $1 / 2$ " deeper than the pin, the preferred method is to achieve a friction fit between the pin and the rock. The hole tends to widen near the top, because the bit pivots about its tip early in the drilling. Drill the hole, and blow all dust out of the hole with a long flexible tube. And check how far the pin will fall into the hole. Stainless brass pin about 3/4-inch pin were anchored into the holes using epoxy. Data at these sites were recorded with conventional 30-second samples continuously for more than three day.

\section{GPS Processing}

The GPS data obtained from the campaign site has been converted into RINEX observation files and quality check has been performed using TEQC (Translation, Editing and Quality Checking Software). The quality

Table 1. Campaign stations with location.

\begin{tabular}{|c|c|c|c|c|c|}
\hline Sl. no. & Station Name & Identifier & Latitude & Longitude & Height (m) \\
\hline 1 & TIWARI GAON & TWGN & $28^{\circ} 13^{\prime} 26.219^{\prime \prime}$ & $95^{\circ} 50^{\prime} 02.210^{\prime \prime}$ & $1367.4 \mathrm{~m}$ \\
\hline 2 & HUNLI & HUNL & $28^{\circ} 19^{\prime} 22.408^{\prime \prime}$ & $95^{\circ} 57^{\prime} 32.036^{\prime \prime}$ & $1222.64 \mathrm{~m}$ \\
\hline 3 & RYALI & RALI & $28^{\circ} 26^{\prime} 59.766^{\prime \prime}$ & $95^{\circ} 51^{\prime} 16.868^{\prime \prime}$ & $738.165 \mathrm{~m}$ \\
\hline 4 & ANGOLIAN & ANGO & $28^{\circ} 33^{\prime} 59.744^{\prime \prime}$ & $95^{\circ} 50^{\prime} 40.488^{\prime \prime}$ & $668.69 \mathrm{~m}$ \\
\hline 5 & AMOLIN & AMOL & $28^{\circ} 46^{\prime} 40.194^{\prime \prime}$ & $95^{\circ} 54^{\prime} 02.618^{\prime \prime}$ & $1184.27 \mathrm{~m}$ \\
\hline 6 & KAMLANG NAGAR & KNGR & $27^{\circ} 45^{\prime} 21.870^{\prime \prime}$ & $96^{\circ} 21^{\prime} 30.966^{\prime \prime}$ & $341.394 \mathrm{~m}$ \\
\hline 7 & TIDDING & TDGN & $27^{\circ} 58^{\prime} 21.859^{\prime \prime}$ & $96^{\circ} 23^{\prime} 46.851^{\prime \prime}$ & $361.171 \mathrm{~m}$ \\
\hline 8 & HAYULIANG & HAYU & $28^{\circ} 04^{\prime} 54.520^{\prime \prime}$ & $96^{\circ} 31^{\prime} 12.739 "$ & $590.403 \mathrm{~m}$ \\
\hline 9 & WALLONG & WALG & $28^{\circ} 07^{\prime} 52.054^{\prime \prime}$ & $96^{\circ} 00^{\prime} 57.603^{\prime \prime}$ & $1197.95 \mathrm{~m}$ \\
\hline
\end{tabular}

Table 2. Permanent station with location (Ellipsoidal coordinates).

\begin{tabular}{cccccc}
\hline Sl. no & Station Name & Identifier & Latitude & Longitude & Height (m) \\
\hline 1 & ANINI & ANIN & 95.901 & 28.801 & 1668.03 \\
\hline
\end{tabular}


check plots of all the GPS data were carefully examined and the data with high cycle clips were carefully examined and the data with high cycle clips multipath and $<12$ $\mathrm{h}$ observation were removed from the analysis. The GPS data were processed using the GAMIT/GLOBK software package. In addition to the GPS data collected from study area, we processed data from a number of International Global Navigational Satellite System Service (IGS) permanently operating stations (Figure 3 ) in and around the region (bahr, coco, hrao, iisc, karr, kit3, kunm, lhaz, ntus, hyde, wuhn, bako). We combined our own solution with daily solutions of global IGS stations processed and archived at the Scripps Orbital and Permanent Array Centre (SOPAC). The International Terrestrial Reference Frame (ITRF) 2008 was defined by applying translation and rotation parameters that minimize the horizontal velocities of sites assumed to lie within the stable plate interior.

\section{GPS Data and Analysis}

Campaign mode has been started from the month of August 2008 with 9 (nine) different stations in the Mishmi block of Arunachal Pradesh for the Geodynamic studies.

\section{Results}

The GPS data processing is carried out and baseline data are plottedin time series plots (Figure 4) for determination of crustal velocities. From all the campaign stations well distributed in Eastern Himalayan Syntaxis show the resultant vector of HAYU (Hayuliang) is the highest which shows $4.20 \mathrm{~mm} / \mathrm{yr}$ with an azimuth of $45^{\circ} \mathrm{N}$ whereas TDNG (Tidding) shows the lowest $1.46 \mathrm{~mm} / \mathrm{yr}$ with an azimuth of $49^{\circ} \mathrm{N}$ (Figures 5 and 6). Above these, the permanent station ANIN (Anini) which is located in the upper Dibang valley shows $0.77 \mathrm{~mm} / \mathrm{yr}$ with an azimuth of $46.57^{\circ} \mathrm{N}$. Most of the campaign stations fall on the Mishmi block. The overall resultant vector average for all the sites is $2.26 \mathrm{~mm} / \mathrm{yr}$ with and azimuth of $45.88^{\circ} \mathrm{N}$. It indicates the simmering tectonic stresses in a clock wise direction, which may be one of the telltale evidence for a damaging earthquake around the Eastern Himalayan Syntaxis. Mishmi Block in the EHS seems to be of very slow crustal velocity comparing to the neighbouring regions such as Tibetan Plateau, North \& South China and Burmese Arc region. We have compared the GPS results from this region and made an attempt for the first time for our investigated EHS, which is indentor

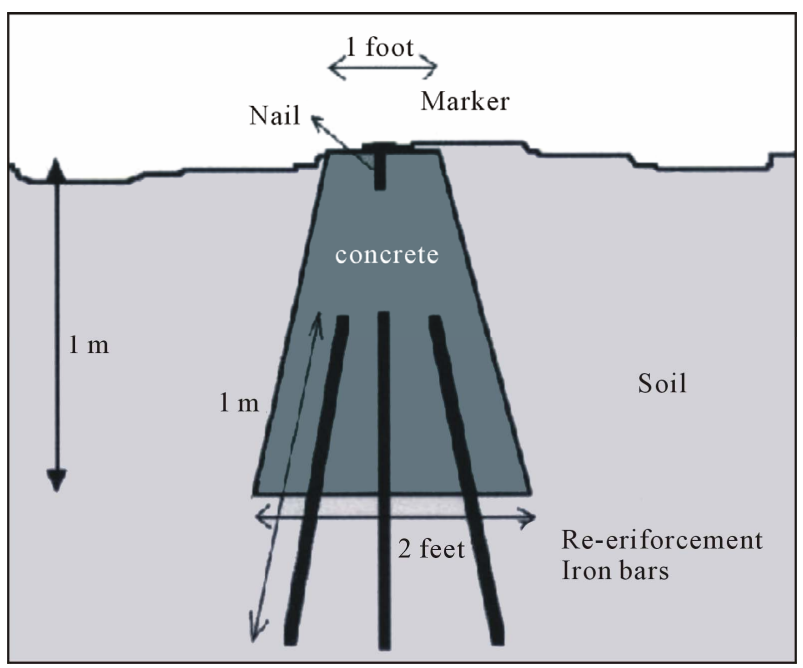

Figure 2. Schematic of campaign GPS monument.

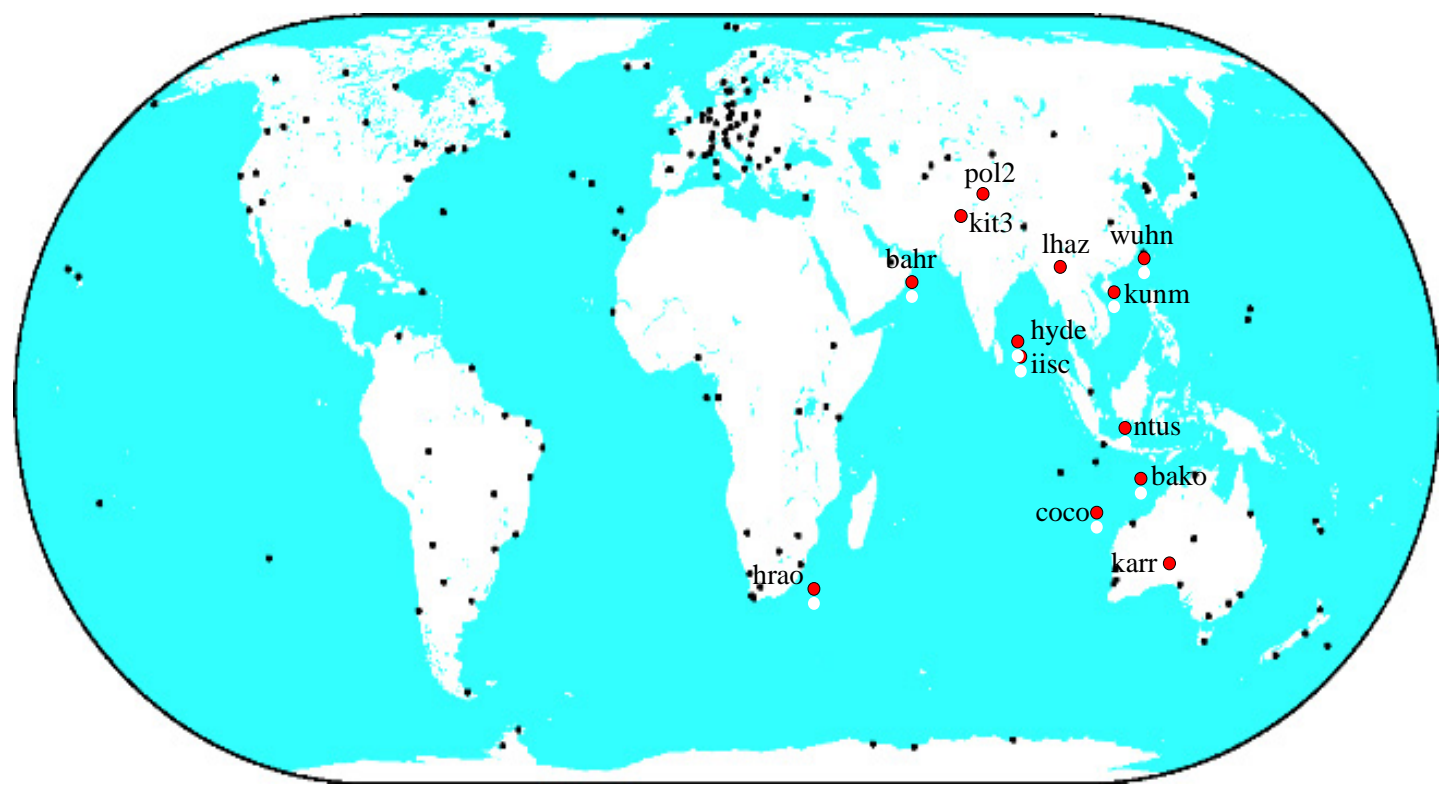

Figure 3. IGS stations (coloured) used in the processing. 

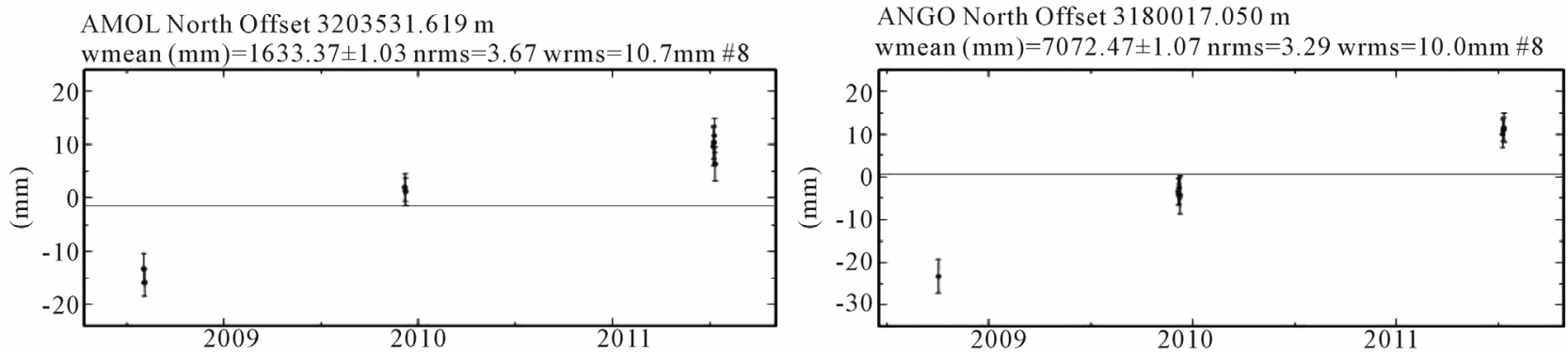

AMOL East Offset $9357215.992 \mathrm{~m}$

Wmean $(\mathrm{mm})=6080.14 \pm 0.94 \mathrm{nrms}=22.43 \mathrm{wrms}=59.4 \mathrm{~mm} \quad \# 8$
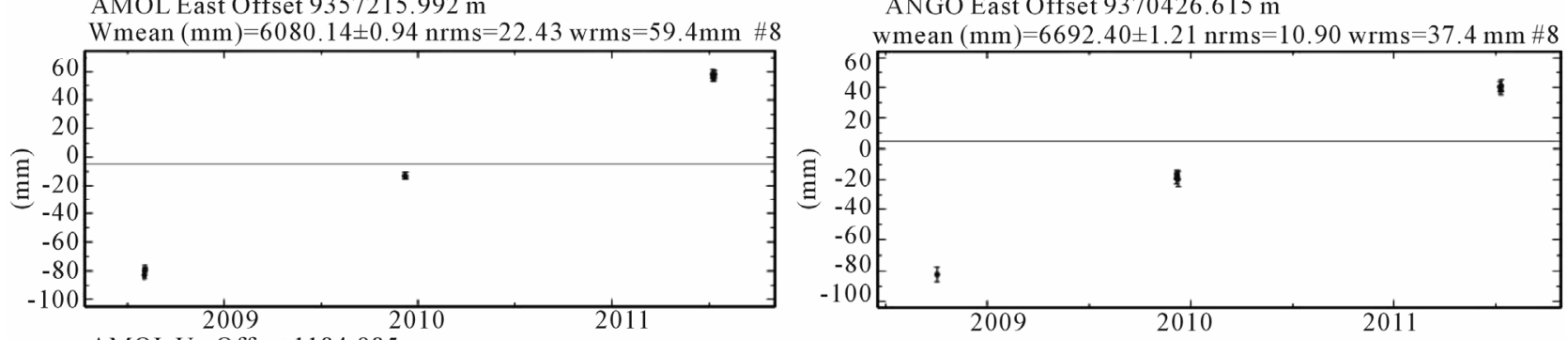

AMOL Up Offset $1184.985 \mathrm{~m}$

Wmean $(\mathrm{mm})=5012.84 \pm 4.52 \mathrm{nrms}=1.54 \mathrm{wrms}=19.6 \mathrm{~mm} \# 8$

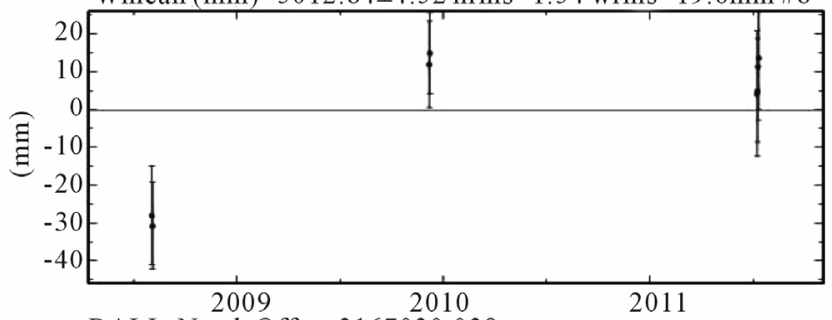

2011

RALL North Offset $3167030.038 \mathrm{~m}$

wmean $(\mathrm{mm})=56.85 \pm 1.28 \mathrm{nrms}=4.35 \mathrm{wrms}=14.7 \mathrm{~mm} \mathrm{\# 7}$

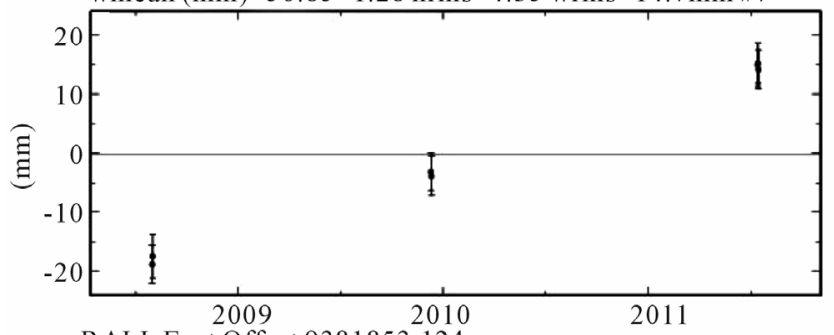

R $\Lambda$ LL East Offset $9381853.124 \mathrm{~m}$

2011

wmean $(\mathrm{mm})=3197.98 \pm 1.37 \mathrm{nrms}=16.31 \mathrm{wrms}=59.3 \mathrm{~mm} \# 7$

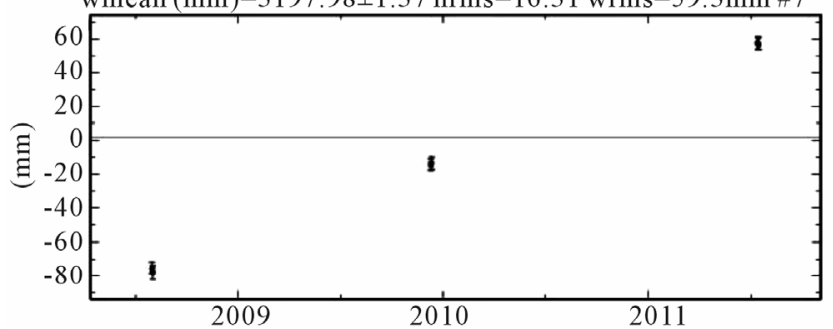

RALL Up Offset $738.925 \mathrm{~m}$

wmean $(\mathrm{mm})=8918.57 \pm 7.01 \mathrm{nrms}=0.26 \mathrm{wrms}=4.9 \mathrm{~mm} \# 7$
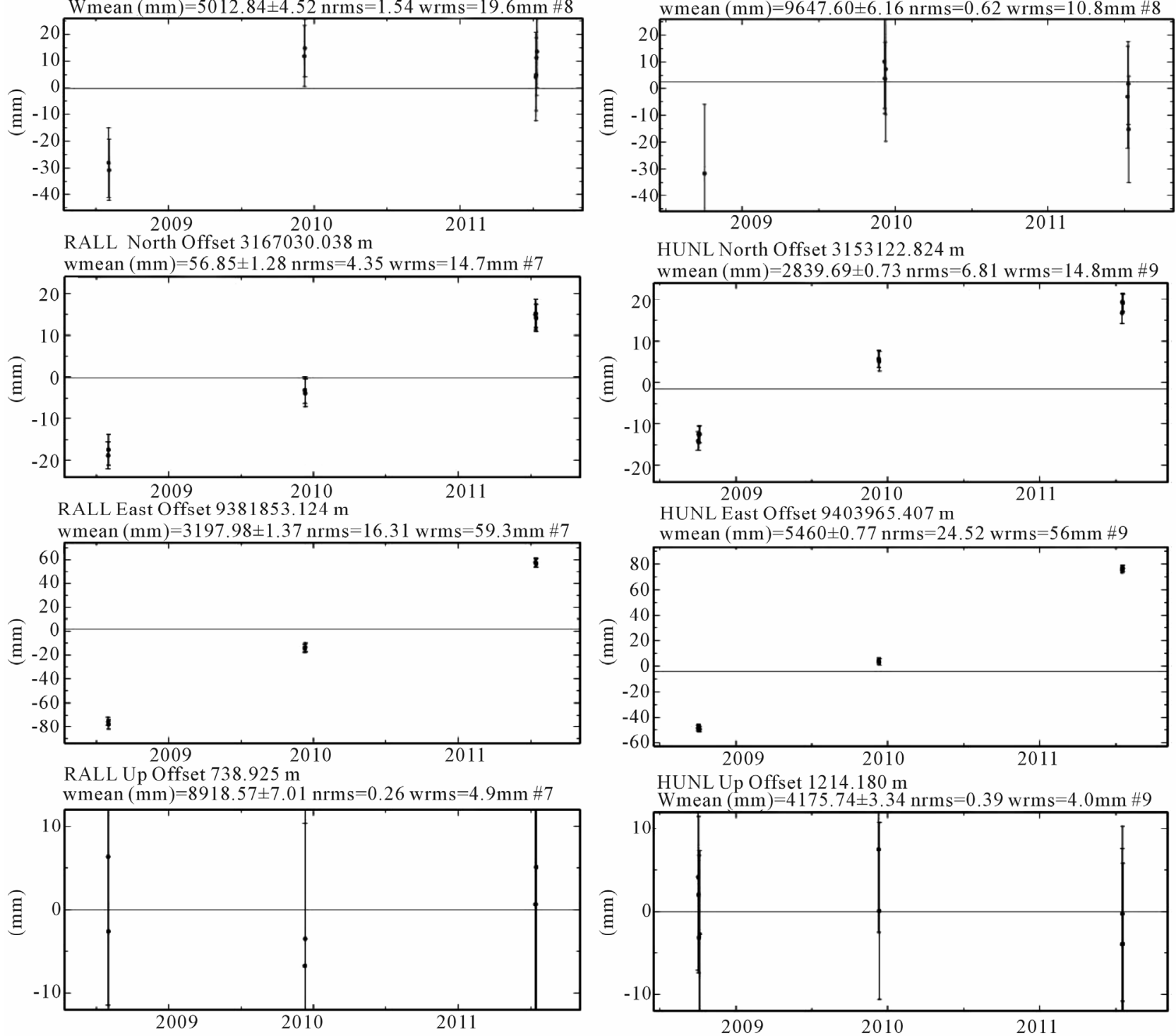

HUNL North Offset $3153122.824 \mathrm{~m}$

wmean $(\mathrm{mm})=2839.69 \pm 0.73 \mathrm{nrms}=6.81 \mathrm{wrms}=14.8 \mathrm{~mm} \# 9$

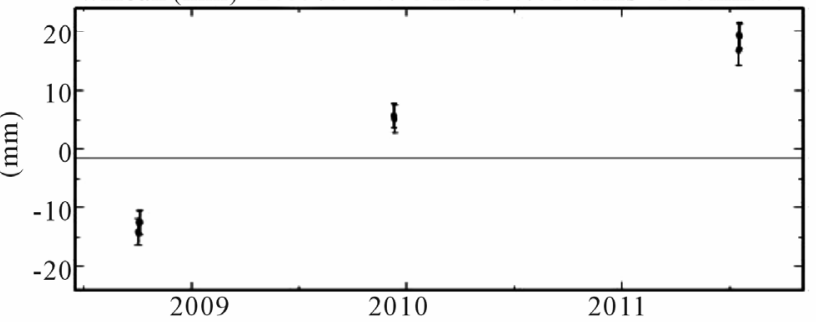

HUNL East Offset $9403965.407 \mathrm{~m}$

wmean $(\mathrm{mm})=5460 \pm 0.77 \mathrm{nrms}=24.52 \mathrm{wrms}=56 \mathrm{~mm} \# 9$

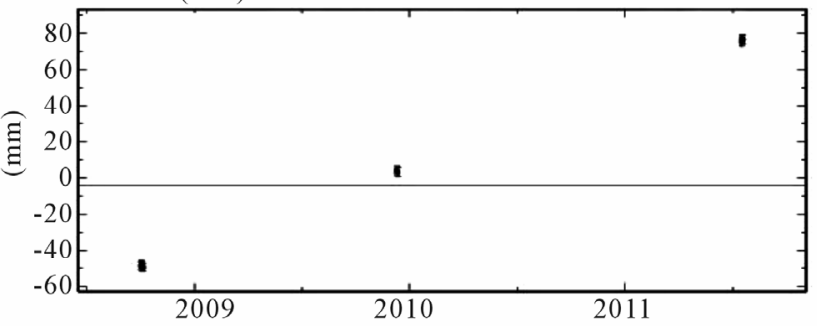

HUNL Up Offset $1214.180 \mathrm{~m}$

Wmean $(\mathrm{mm})=4175.74 \pm 3.34 \mathrm{nrms}=0.39 \mathrm{wrms}=4.0 \mathrm{~mm} \# 9$

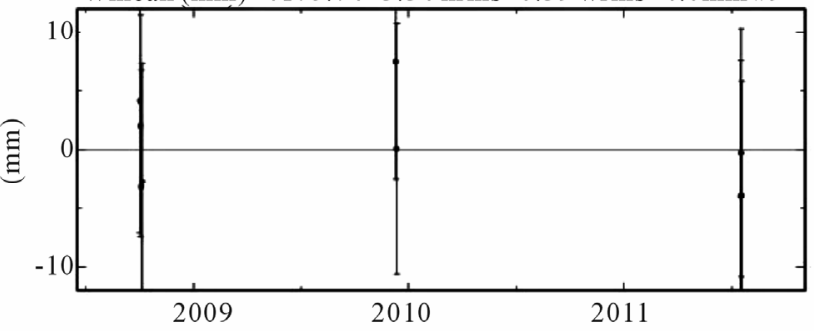




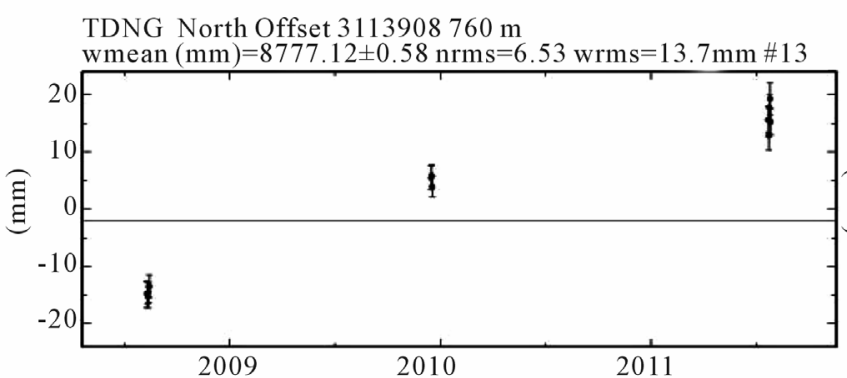

HAYU North Offset $3126050.243 \mathrm{~m}$

wmean $(\mathrm{mm})=252.50 \pm 1.67 \mathrm{nrms}=1.68 \mathrm{wrms}=7.9 \mathrm{~mm} \mathrm{\# 8}$

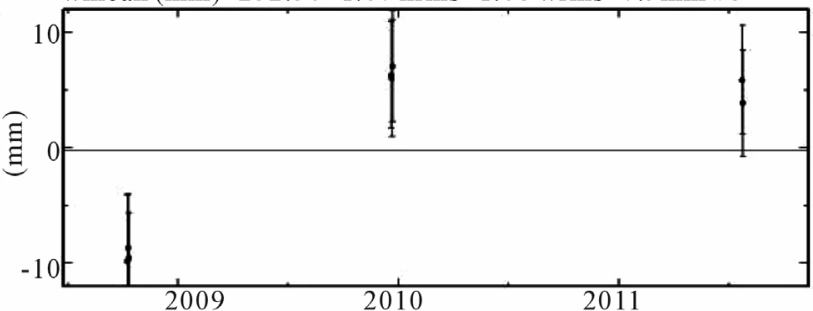

HAYU East Offset $9479808.507 \mathrm{~m}$

TDNG East Offset $9477223.725 \mathrm{~m}$

wmean $(\mathrm{mm})=8563.32 \pm 1.66 \mathrm{nrms}=11.41 \mathrm{wrms}=53.7 \mathrm{~mm} \mathrm{\# 8}$
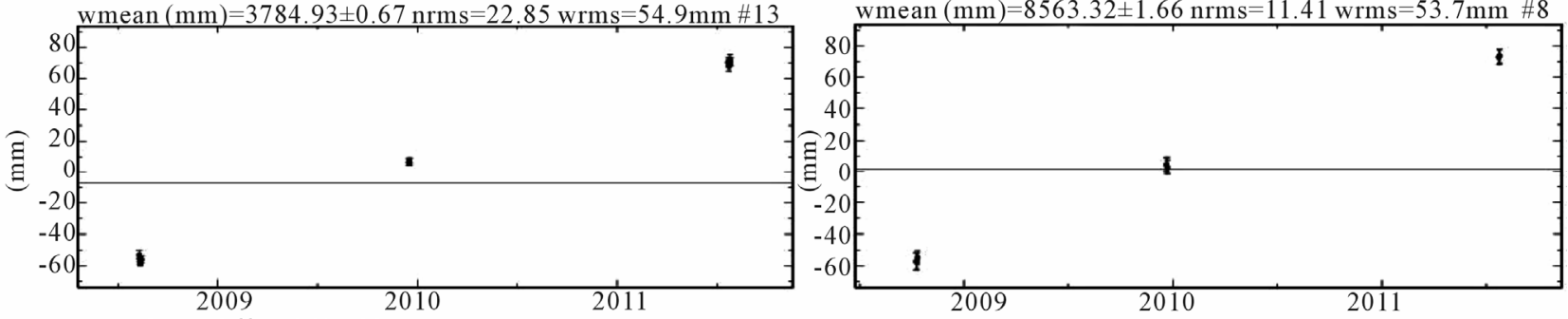

Up Offset $360.722 \mathrm{~m}$

wmean $(\mathrm{mm})=723.11 \pm 2.73 \mathrm{nrms}=0.45 \mathrm{wrms}=4.4 \mathrm{~mm} \# 13$

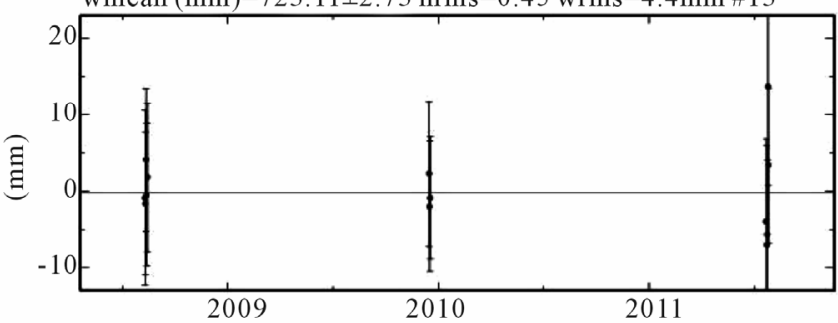

p $591.452 \mathrm{~m}$

wmean $(\mathrm{mm})=1414.36 \pm 9.98 \mathrm{nrms}=0.77 \mathrm{wrms}=21.8 \mathrm{~mm} \# 8$

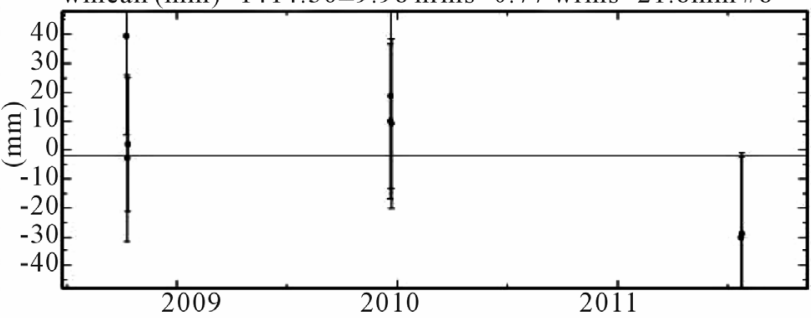

TWGN North Offset $3141874.765 \mathrm{~m}$

wmean $(\mathrm{mm})=4787.01 \pm 0.97 \mathrm{nrms}=6.30 \mathrm{wrms}=17.4 \mathrm{~mm} \# 8$

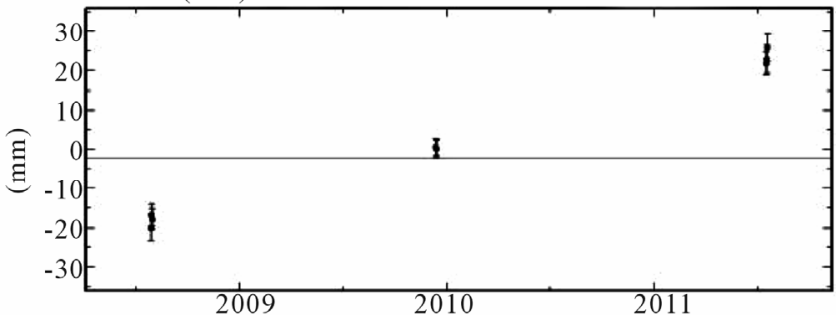

KNGR North Offset $3089741.037 \mathrm{~m}$

wmean $(\mathrm{mm})=1055.14 \pm 1.15 \mathrm{nrms}=4.90 \mathrm{wrms}=14.9 \mathrm{~mm} \# 7$

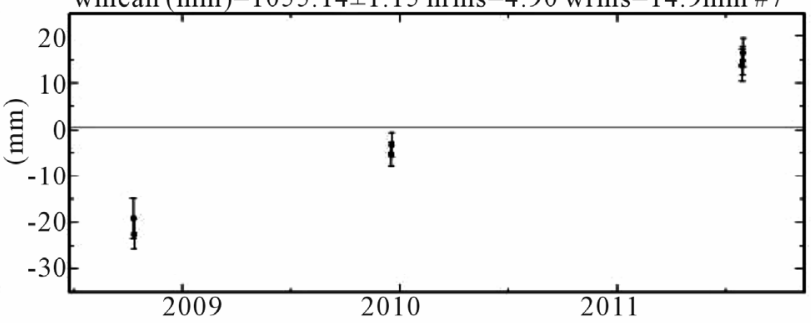

TWGN East Offset $9399824.016 \mathrm{~m}$

wmean $(\mathrm{mm})=4082.01 \pm 0.91 \mathrm{nrms}=21.42 \mathrm{wrms}=55.0 \mathrm{~mm} \# 8$

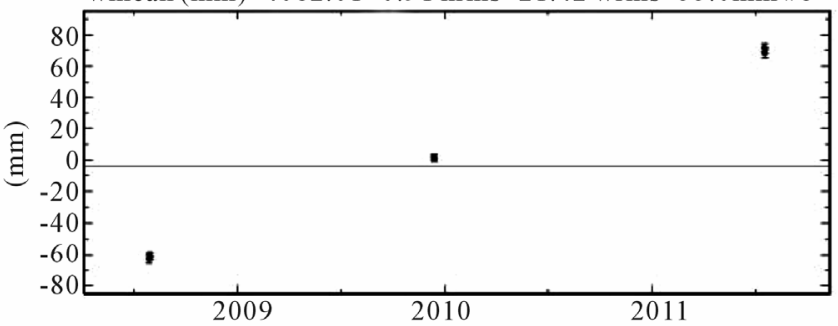

KNGR East Offset $9492382.799 \mathrm{~m}$

wmean $(\mathrm{mm})=2865.69 \pm 1.14 \mathrm{nrms}=15.85 \mathrm{wrms}^{2}=47.9 \mathrm{~mm} \# 7$

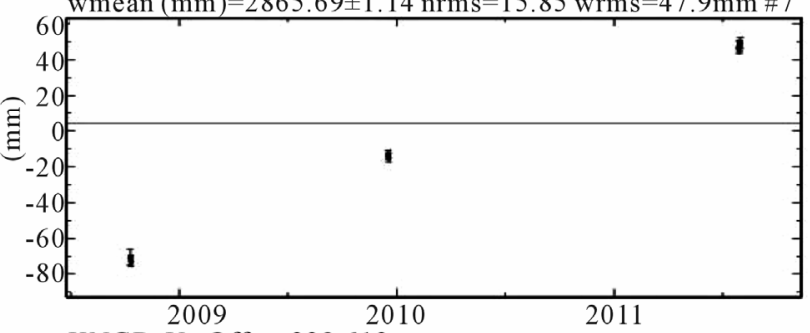

( 0 Offset $1371.503 \mathrm{~m}$

wmean $(\mathrm{mm})=1501.01 \pm 4.19 \mathrm{nrms}=0.58 \mathrm{wrms}=6.9 \mathrm{~mm} \# 8$

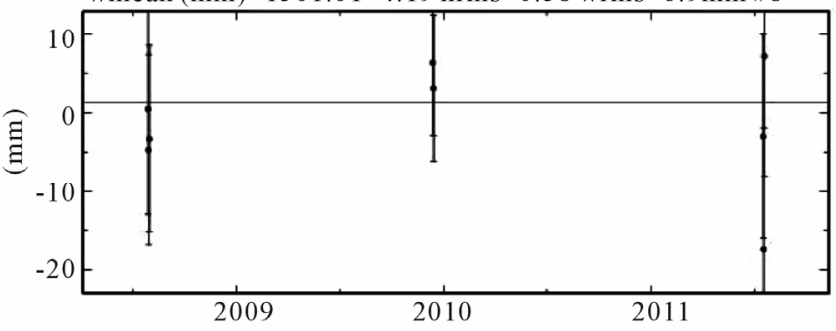

Up Offset $339.613 \mathrm{~m}$

wmean $(\mathrm{mm})=9628.21 \pm 5.11 \mathrm{nrms}=0.41 \mathrm{wrms}=5.6 \mathrm{~mm} \# 7$

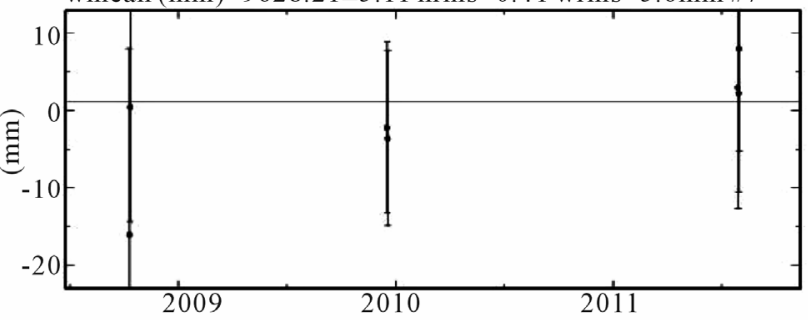




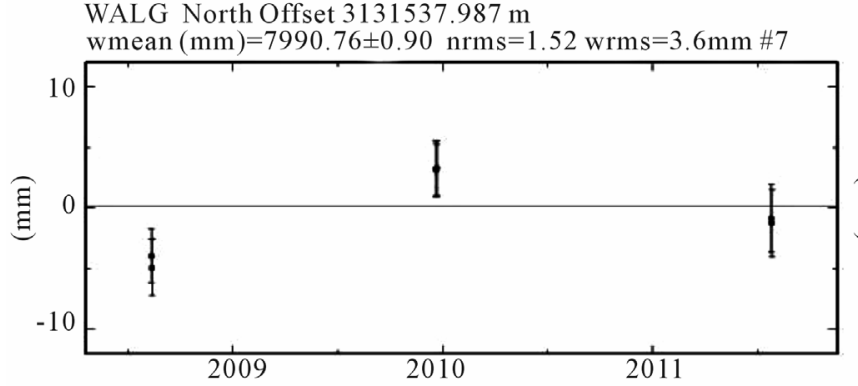

WALG East Offset $9523925.079 \mathrm{~m}$

wmean $(\mathrm{mm})=5038.50 \pm 1.03 \mathrm{nrms}=16.84 \mathrm{wrms}=46.0 \mathrm{~mm} \# 7$

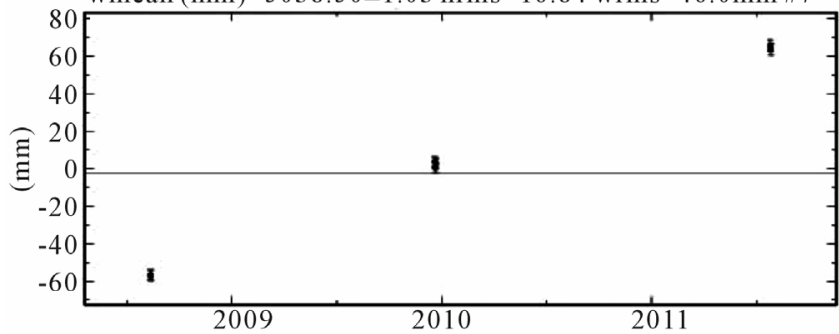

WALG Up Offset $1199.712 \mathrm{~m}$

wmean $(\mathrm{mm})=9731 \pm 4.21 \mathrm{nrms}=1.42 \mathrm{wrms}=15.8 \mathrm{~mm} \# 7$

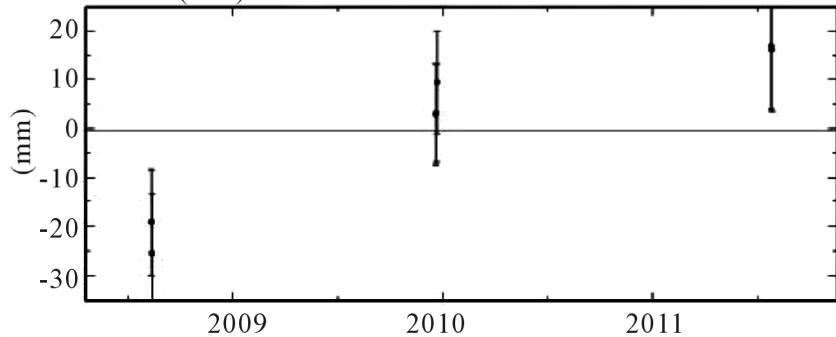

ANIN North Offset $3206140.219 \mathrm{~m}$

wmean $(\mathrm{mm})=233.88 \pm 0.37 \mathrm{nrms}=5.37 \mathrm{wrms}=11.4 \mathrm{~mm} \# 34$

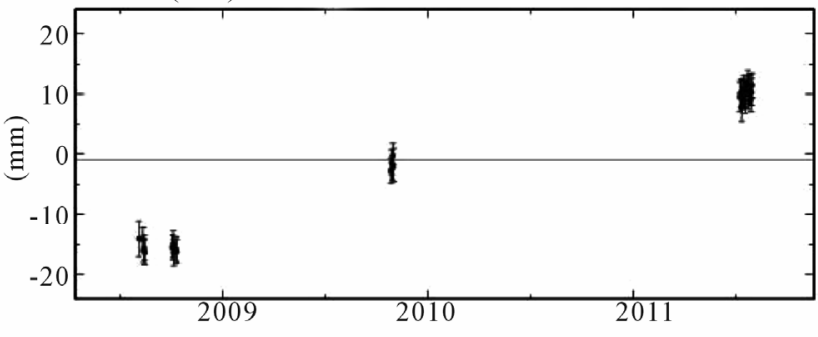

ANIN East Offset $9355021.757 \mathrm{~m}$

wmean $(\mathrm{mm})=1839 \pm 0.40 \mathrm{nrms}=24.84 \mathrm{wrms}=58.1 \mathrm{~mm} \# 34$

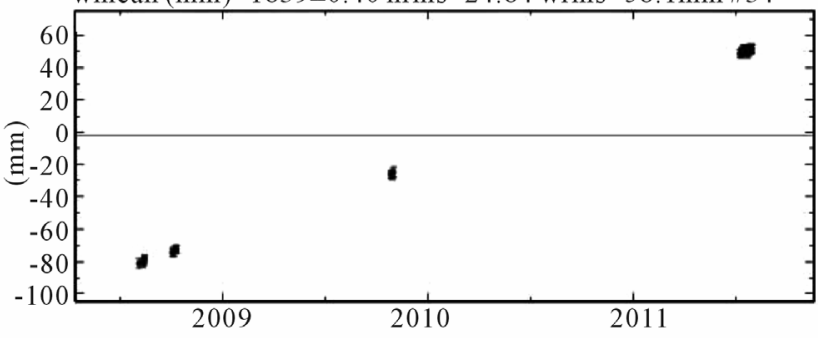

ANIN Up Offset $1668.039 \mathrm{~m}$

wmean $(\mathrm{mm})=8035.53 \pm 1.65 \mathrm{nrms}=0.64 \mathrm{wrms}=6.1 \mathrm{~mm} \# 34$

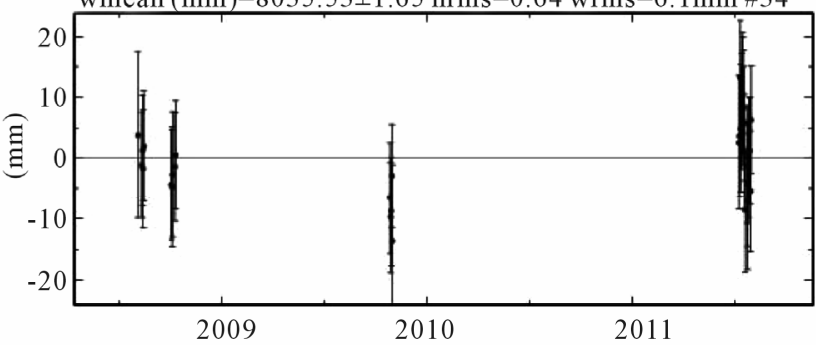

Figure 4. Time series plots of the (nine) campaign sites.

corner of the eastern Himalayan terrain. The progressive deformation related to the anti-clock wise rotation of the Indian plate resulted therecent underthrusting of the Brahmaputra alluvium along the MT, and the recent deformation along the northern splays of the N-S trending dextral Sagaing strike-slip fault along which the Indian plate has moved towards north relative to the south China. It is inferred that the recent uplift of the high-grade basement rocks along the Namche Barwa syntaxis or the EHS [40] has developed the gravity collapse related steep normal faults along the mountain frontal part of the North Eastern Himalaya, Arunachal Pradesh. Thus the active tectonics seems to be associated with the later deformation that penetrated within the Indian plate from the tectonic deformation distributed along the margins of the Indian, South China and Indo-Burmese plates, including the recent uplift of the Eastern Himalayan Syntaxis [41]. The details are described in the discussion.

\section{Discussion}

In order to understand the comparative deformation patterns of EHS, we like to compare the deformation rate at Tibetan Plateau, North \& South China as there is clock- wise rotation of this block around the EHS. The Pn velocities and anisotropies around EHS and surrounding regions are obtained through seismic tomography [1]. The fast directions of $\mathrm{Pn}$, the polarization directions of SKS, GPS and the maximum compressive stress are consistent in the regions to the north and east of the EHS and rotate around the EHS. The anisotropy may result from the simple shear caused by the eastward mass flow of the Tibetan Plateau relative to static EHS and Yangtze Platform. The crustal shortening accommodates most of India's penetration into Eurasia has been demonstrated [2]. The Tibetan plateau moves eastward and is accommodated through the rotation of material around eastern syntaxis. North China \& South China blocks and East of Tibetan plateau, moves coherently eastsoutheastward at the rates of $2-8 \mathrm{~mm} / \mathrm{yr}$ and $6-11 \mathrm{~mm} / \mathrm{yr}$ respectively, with respect to stable Eurasia. It indicates that the EHS is one of the block which has very low crustal velocity, however, it occupies a large slip. Eastern Tibetan plateau show a prominent clockwise rotation, where, stations move eastward in western Sichuan, southeastward in northern Yun-nan, and south-southeastward in southern Yun-nan. These stations show a clockwise rotation 


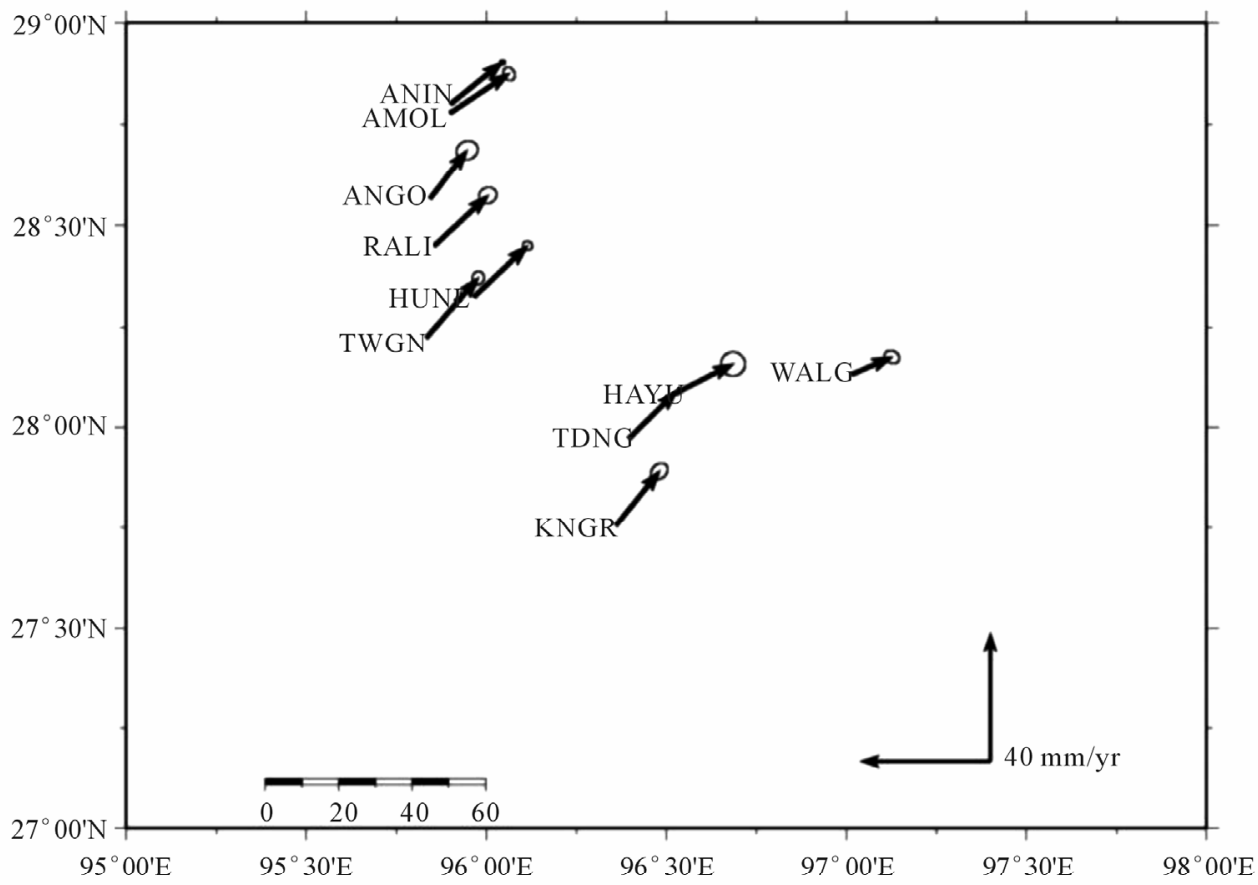

Velocities relative to NONE Input file:msmi_vel.prt

Confidence interval:95 ChiSquare/dol:2.02 Formal Errors Scaled by 1.00

Wed Aug 22 18:43:28 IST 2012

Figure 5. Velocity vector plot with respect to eurasian plate for mishmi campaign stations, arunachal pradesh.

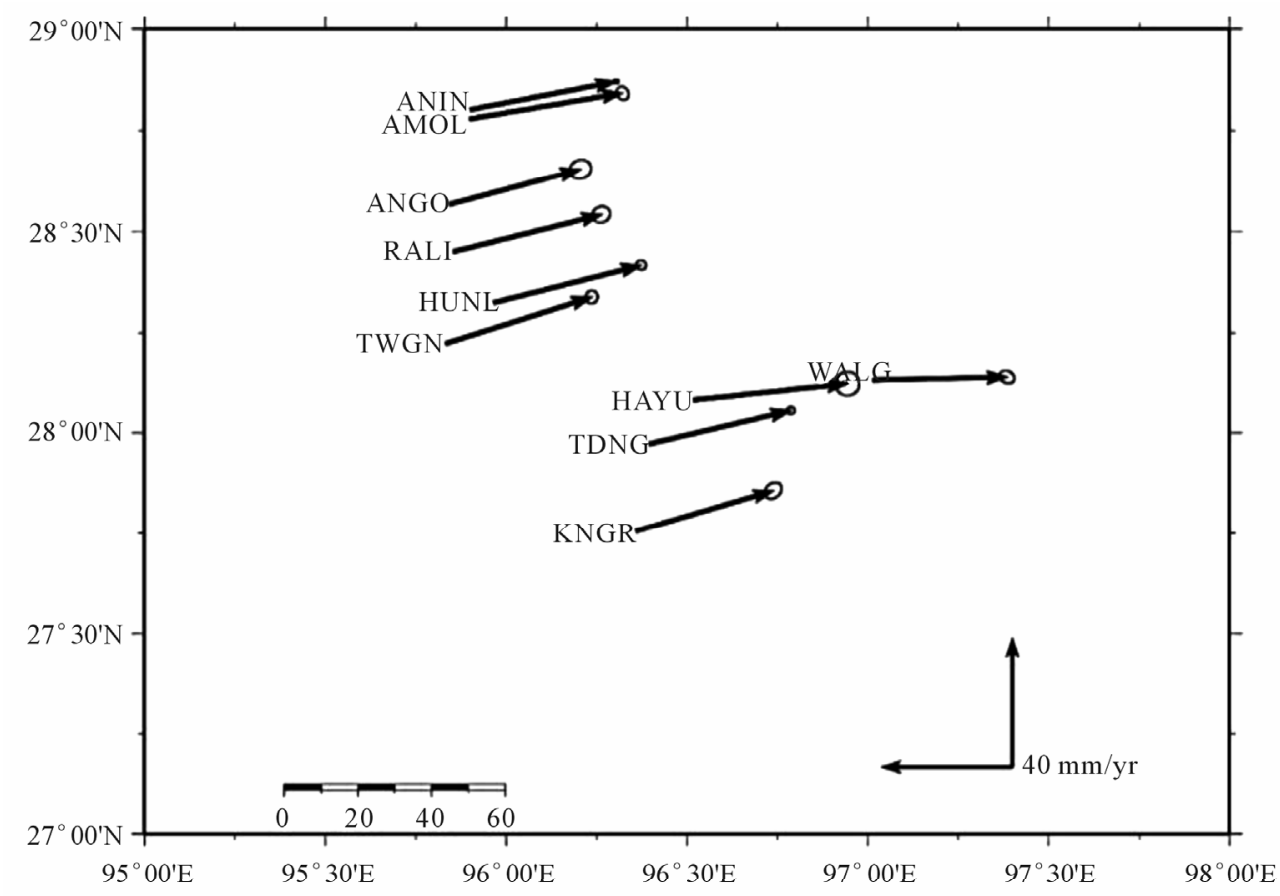

Velocities relative to NONE Input file:msmi vel.prt

Confidence interval:95 ChiSquare/dol:2.02 Formal Errors Scaled by 1.00

Wed Aug 22 18:41:01 IST 2012

Figure 6. Velocity vector plot with respect to ITRF2008 for mishmi campaign stations, arunachal pradesh. 
around the Eastern Himalayan Syntaxis. Eastern Tibetan Plateau moves eastward faster (21 to $26 \mathrm{~mm} / \mathrm{year}$ ) than North China (14 to $17 \mathrm{~mm} /$ year) and $6-10 \mathrm{~mm} / \mathrm{yr}$ in the South China Block. Very low crustal velocity across the Longmen Shan (Figure 7), trending NE-SW at the eastern boundary of the Tibetan plateau ( $3 \mathrm{~mm} / \mathrm{yr}$ ) has been commented [42]. The similar trend of the EHS with much lower rates of the average crustal velocity $2.66 \mathrm{~mm} /$ yr indicates typical deformation history of these two tectonically strained blocks. However, the clockwise rotation of the velocity vectors around the Eastern Himalayan Syntaxis suggests an alternate explanation, consistent with that proposed [43,44]. They analysed 183 focal plane solutions and inferred that the curvature of the Indo-
Burman ranges is controlled by the geometry of the interface between the more steeply dipping part of the Indian plate and the leading edge of the overriding Burma platelet. Shallow earthquakes beneath the Indo-Burman ranges are primarily confined to the underthrusting Indian plate. Their focal mechanisms indicate strike-slip faulting and north-south shortening parallel to the eastern margin of the Indian plate. The extruding Tibetan crust rotates around the Eastern Himalayan Syntaxis, causing the southeastward to southward velocities observed in southern Yun-nan Province. This clockwise rotation continues southwestward into Myanmar is seems to be possible, because east-west contraction is suggested in western Myanmar, based on numerical kinematic models $[44,45]$.

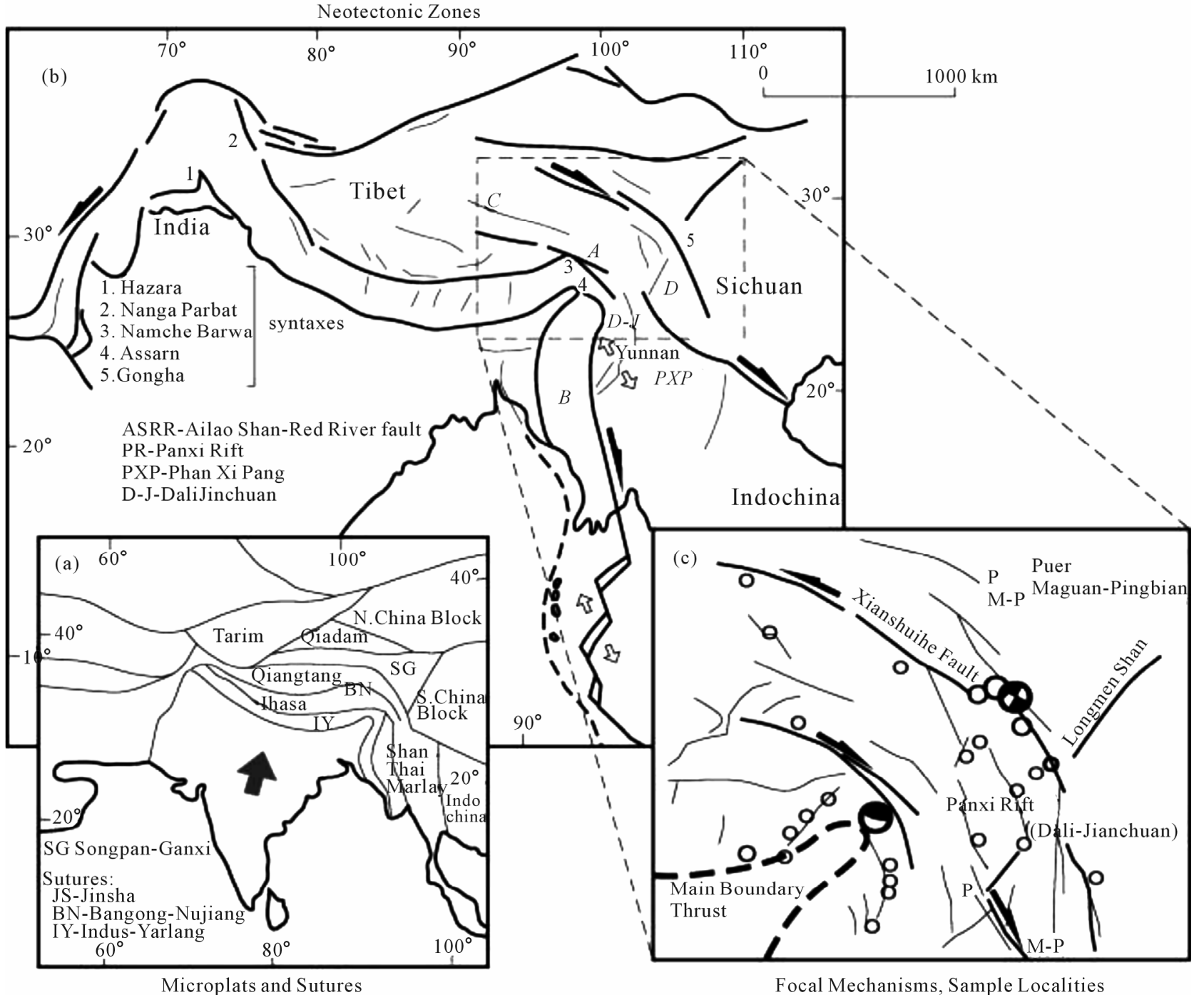

Figure 7. Tectonic maps of: (a) Microplates and sutures in central and southeastern Asia (adapted from [53]); (b) Neotectonic zones: (A) Dextral strike-slip faulting at and east of the eastern (Assam-NamcheBarwa) syntaxis (Jiali-Parlung and Po Qu fault systems), (B) Conjugate Batang-Litang fault system, (C) Sinistral strike-slip faulting within central Tibet and westernmost Sichuan (Ganzi-Yashu and Xianshui He fault systems), (D) Thrusting along the Longmen Shan thrust belt in western Sichuan; and (c) The study area in western Yunnan showing focal mechanisms for moderate and large seismic events between 1964 and 1989 and major faults in eastern Tibet and western Sichuan. 
Based on the comparison of various GPS studies, the velocity field indicates that relative to South China Block, all crustal motion is accommodated by clockwise rotation around the eastern Himalayan syntaxis and by strike-slip faults and shortening within the NE Tibetian region. There is northward motion within the foreland of the NE part of the Tibetan Plateau, but only very small movement of crustal material eastward beyond the eastern boundary of the plateau. The results from three rounds of GPS measurements reveal new characteristics of current movements in East and SE-Asia [46]. In the ITRF97 reference frame, motion of sites on SSC are coherently due east about an Euler pole roughly approximating that of Eurasia but with a velocity that is one third higher than the eastward directed movement of Eurasia. The eastwards motion of India is to a large extent compensated by the eastward directed motion of SE-Asia. This is still the case if we assume that the NUVEL1Aconvergence direction between India and Eurasia is approximately right whereas the velocity is an overestimate of about 4 $\mathrm{mm} / \mathrm{yr}$ of the actual velocity [47,48]. A lower velocity of India with respect to Eurasia however results in a lower rate of differential dextral motion between India and SSC along the Sagaing and related faults.

The new GPS measurements unambiguously document a gradual change in surface velocity vectors from northward convergence to eastward motion of material north of the syntaxis [49]. They combined with existing geodetic data and the GPS velocity field, which reveals a conspicuous clockwise motion of crustal material (relative to the South China block) around the eastern Himalayan syntaxis and coincident with the eastern edge of the Indian plate arcuate band [42,50,51]. This clockwise rotation continues south to $\sim$ lat $26^{\circ} \mathrm{N}$ in Yunnan province, where motion of material turns to the west in western Yunnan. East of long $102^{\circ} \mathrm{E}$, the GPS velocity vectors turn east, diverging around the Sichuan Basin. The crustal deformation rates of Eastern Himalaya was determined by two permanent GPS station located at Bomdila and Tawang [52]. The crustal velocity at Bomdila and Tawang is $20.26 \mathrm{~mm} / \mathrm{yr} \mathrm{N}$ and $39 \mathrm{~mm} / \mathrm{yr}$ E. However, the permanent GPS site at Bomdilla (BOMD) gives ITRF 2000 horizontal velocity of $20.36 \pm 0.4 \mathrm{~mm} / \mathrm{yr}(\mathrm{N})$ and $39.04 \pm 0.4 \mathrm{~mm} / \mathrm{yr}$ (E) which is different from that of the Shillong Plateau stations as well as Tezpur. In the Indian reference frame, BOMD gives a southward velocity of $10.6 \mathrm{~mm} / \mathrm{yr}$. Baselines of Bomdilla permanent site show convergence of $6 \pm 0.3 \mathrm{~mm} / \mathrm{yr}$ with Tezpur and $9 \pm 0.3$ $\mathrm{mm} / \mathrm{yr}$ with Lhasa. This suggests that approximately 15 $\mathrm{mm} / \mathrm{yr}$ of convergence is being accommodated across the Arunachal Himalaya. The Tezpur-Lhasa baseline shows a convergence of $15 \pm 0.1 \mathrm{~mm} / \mathrm{yr}$ which also supports the above observation. The measurements in the Arunachal Himalaya suggest that strain is accumulating both in the
Lesser-Outer Himalaya ( 6 mm/yr between Bomdilla and Tezpur) as well as in the Higher and Tethyan Himalaya ( $\sim 10 \mathrm{~mm} / \mathrm{yr}$ between Bomdilla and Tawang). The discussion leads to an interesting issue of the highly strained EHS with a very low crustal velocity. The EHS is almost a stable arc and yield enormous strain, if we compare the crustal velocity at Bomdila or Tezpur, which falls within the Indian plate. We can also compare its velocity with its Tibetan plateau, North \& South China and Burmese arc region which rotates in a clockwise manner with the high crustal velocity. The EHS shows the variations in its crustal velocity along number of E-W trending Mishmi Suture, Tiding Suture and Lohit thrust. The Lohit river anomaly indicates the large variations in crustal velocity in two campaigns points (Figures 8 and 9). The lowest velocity is $1.46 \mathrm{~mm} / \mathrm{yr}$ and highest velocity is $4.20 \mathrm{~mm} / \mathrm{yr}$ within a distance of $20 \mathrm{~km}$, which indicates that the tectonics within these two points has some distinct boundary which is characterised by a marked variations on crustal velocities. It appears to be the result of stream anomaly in the Google map (Figure 8). The meandering patterns of two tributaries are diverted in right lateral direction (Figure 9) and another campaign point indicates the entrenchment of meanders and development of narrow gorge (Figure 8). These morphotectonic observations indicate the surface deformation due to the highly stressed block which depicts a typical evidence for the active tectonics. The detailed trenching and paleoseismic studies might reveal more information on this highly stressed tectonic block. There is seismic record of one great earthquake of 1950 M 8.7 in this region and subsequent shifting of mighty Brahmputra river with enormous land damages instances caused by the same event. The region is also witnessed by the high seismicity which indicates the presence of high strained crust with very low crustal velocity. EHS seems

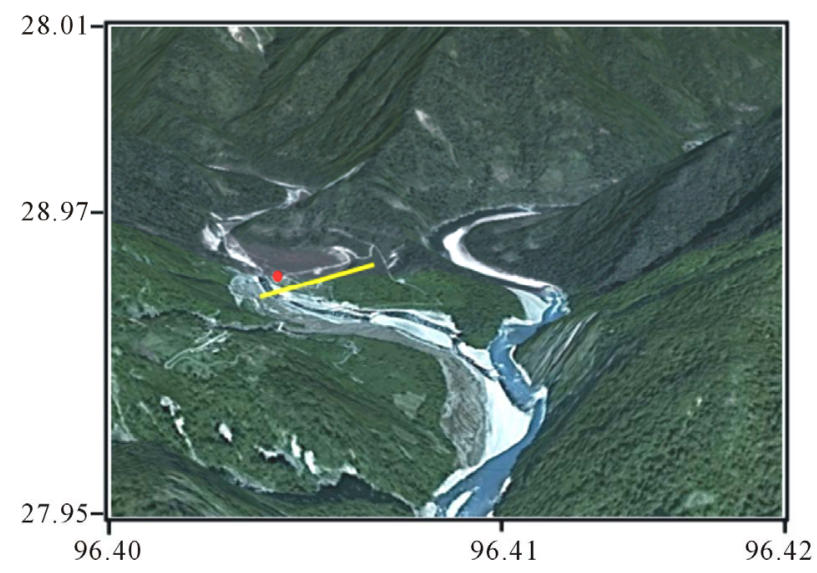

Figure 8. Meandering of two tributaries of Lohit river in low crustal velocity point, which indicates the presence of neotectonic activities in the area (campaign point in red dot). 


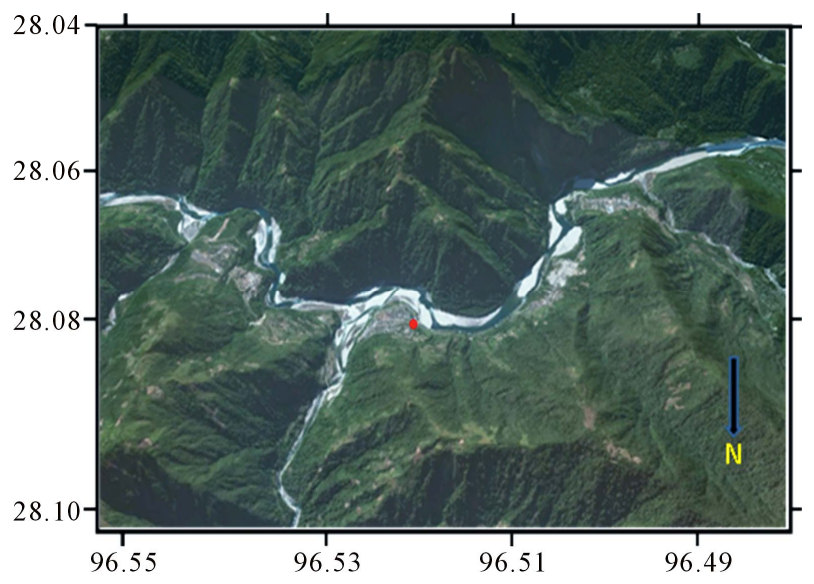

Figure 9. Presence of entrenched meander along one of the campaign point (red dot) shows the uplifting of the bedrock (with highest crustal velocity) due to the neotectonic activities.

to be a stable one with variation in velocities from 1.46 $\mathrm{mm} / \mathrm{yr}$ to $4.20 \mathrm{~mm} / \mathrm{yr}$.

Based on the Pn velocities [1] and geological results, it is found they have distinct correlation: particularly high velocities always exist in old stable regions such as $\mathrm{Si}$ chuan Basin and Indian Plate. Low Pn velocities lie in active tectonic regions, volcanic areas and magmatic rock regions, for example, eastern Tibetan Plateau and North-South Seismic Zone, southern Yunnan province and northern Indochina. Pn anisotropy results show that the fast directions of Pn are clockwise around the EHS from NE in southeastern Tibetan Plateau, then SE to NS in North-South Seismic Zone. The clockwise Pn fast direction maybe results from movement of mass extruded from Tibet under simple shear, which is caused by mass flow in southeastern Tibetan Plateau and North-South Seismic Zone relative to stable EHS and Sichuan Basin (around stable Longmen Shan $>2 \mathrm{~mm} / \mathrm{yr}$ ) (Figure 7). Mishmi block of the EHS is one of the highly strained complex with a very low crustal velocity and vulnerable for the high seismic hazards like the Longman Shan of the Sichuan basin in the China. Remaining Tibetan plateau, North and South China blocks with comparable high crustal velocities in a clock wise direction.

\section{Conclusion}

The simmering tectonic stresses and likely was of relaese of stresses in the Eastern Himalayan Syntaxis can be known through telltale evidences of quaternary activities. The GPS constraints in Mishmi block reveal the very slow mothion of Mishmi complex (2.26 mm/yr with and azimuth of $45.88^{\circ} \mathrm{N}$ ) in relation to Eastern Tibetan Block (6 - $11 \mathrm{~mm} / \mathrm{yr}$ ), China (14 - $20 \mathrm{~mm} / \mathrm{yr}$ ) and Burmese Arc (19 mm/yr). All blocks are moving clockwise at a much slow rates comparing with Indian plate $(65 \mathrm{~mm} / \mathrm{yr})$ on ther SW part, whereas on the NE part is occupied by a very slow moving Longmanshan block ( $3 \mathrm{~mm} / \mathrm{yr})$. This seems to be a deep penetration in the Indian plate on the SW part and Eurasian Plate on the NE part. The remaining Tibetan Plateau and North \& South China Blocks and Burmese Arc moves at much faster rates comparing with these blocks (EHS and Logmanshan). The motion of these blocks is in strike slip manner with sinistral component. The numbers of damaging earthquakes witness the release of enormous stress at Sichuan Basin in the recent past (M7.8 2008; M7.8 2001; M7.3 1975 and M7.3 1970). However, only one damaging Earthquake (M8.7 1950) was triggered at EHS. Therefore, release of stresses through EHS may cause a future damaging earthquake. The further studies on earthquake occurrences and their mechanism in the EHS would be a sincere attempt to trace the size and approximate rupturing of either existing large thrusts trending NW-SE along the Eastern Himalayan Syntaxis.

\section{Acknowledgements}

Authors are grateful for the Ministry of Earth Sciences for providing the financial support to carry out the present work. We also thanks to Dr. Vineet Gahalaut, Scientist National Geophysical Research Institute, Hyderabad for his useful guidance to one of the author.

\section{REFERENCES}

[1] Z. X. Cui and S. P. Pei, "Study on Pn Velocity and Anisotropy in the Uppermost Mantle of the Eastern Himalayan Syntaxis and Surrounding Regions,” Chinese Journal of Geophysics, Vol. 52, No. 9, 2009, pp. 2245-2254.

[2] Q. Wang, et al., "Present-Day Crustal Deformation in China Constrained by Global Positioning System (GPS) Measurements," Science, Vol. 294, No. 5542, 2001, pp. 574-577. doi:10.1126/science.1063647

[3] B. K. Rastogi, "Earthquake Mechanisms and Plate Tectonics in the Himalayan Region,” Tectonophysics, Vol. 21, No. 1-2, 1974, pp. 47-56. doi:10.1016/0040-1951(74)90061-4

[4] A. N. Tandon and H. N. Srivastava, "Focal Mechanisms of Some Recent Himalayan Earthquakes and Regional Plate Tectonics," Bulletin of the Seismological Society of America, Vol. 65, No. 4, 1975, pp. 963-969.

[5] S. Kumar, "Tectonics and Earthquake Mechanism of the Shallow Earthquake Seismic Belt, the Himalaya,” International Journal of Earth Sciences, Vol. 64, No. 1, 1975, pp. 977-992.

[6] U. Chandra, "Seismicity, Earthquake Mechanisms and Tectonics along the Himalayan Mountain Range and Vicinity," Physics of the Earth and Planetary Interiors, Vol. 16, No. 2, 1978, pp. 109-131. doi:10.1016/0031-9201(78)90083-3

[7] P. Molnar and W. P. Chen, "Focal Plane and Fault Plane 
Solutions of Earthquakes under the Tibetan Plateau," Journal of Geophysical Research, Vol. 88, No. B2, 1983, pp. 1180-1196. doi:10.1029/JB088iB02p01180

[8] L. Baranowski, J. Ambuster, L. Seeber and P. Molnar, "Focal Depths and Fault Plane Solutions of Earthquakes and Active Tectonics in Himalaya," Journal Geophysical Research, Vol. 89, No. B8, 1984, pp. 6918-6928. doi:10.1029/JB089iB08p06918

[9] M. Mukhopadhyay, "Seismotectonics of Transverse Lineaments in the Eastern Himalaya and Its Foredeep," Tectonophysics, Vol. 109, No. 3-4, 1984, pp. 227-240. doi:10.1016/0040-1951(84)90142-2

[10] S. Biswas and A. Das Gupta, "Some Observations on the Mechanism Earthquakes in the Himalaya and the Burmese Arc,” Tectonophysics, Vol. 122, No. 3-4, 1986, pp. 325-343. doi:10.1016/0040-1951(86)90150-2

[11] Coward, "The Tectonic History of Kohistan and Its Implications for Himalayan Structure," Journal of the Geological Society, Vol. 144, 1987, pp. 377-391. doi:10.1144/gsjgs.144.3.0377

[12] Dasgupta, “Active Tectonic Feature in the Central Part of Himalaya,” Tectonophysics, Vol. 136, No. 3-4, 1987, pp. 255-264. doi:10.1016/0040-1951(87)90028-X

[13] R. K. Verma and K. A. V. L. Prasad, "Analysis of Gravity Fields in the Northwestern Himalayas and Kohistan Region Using Deep Seismic Sounding Data," Geophysical Journal of the Royal Astronomical Society, Vol. 91, No. 3, 1987, pp. 869-889. doi:10.1111/j.1365-246X.1987.tb01672.x

[14] H. Maung, "Transcurrent Movements in the Burma-Andaman,” Geology, Vol. 15, 1987, pp. 911-912. doi:10.1130/0091-7613(1987)15<911:TMITBS>2.0.CO;2

[15] Curry, "Tectonics of the Andaman Sea and Burma," Memoirs-American Association of Petroleum Geologists, Vol. 29, 1979, pp. 189-198.

[16] J. F. Ni, et al., "Accretionary Tectonics of Burma and the Three-Dimensional Geometry of the Burma Subduction Zone,” Geology, Vol. 17, No. 1, 1989, pp. 68-71. doi:10.1130/0091-7613(1989)017<0068:ATOBAT>2.3.C $\mathrm{O} ; 2$

[17] W. P. Chen and P. Molnar, "Source Parameters of Earthquakes and Intraplate Deformation beneath the Shillong Plateau and Northern Indo-Burma Region,” Journal of Geophysical Research, Vol. 95, No. B8, 1990, pp. 1252712552. doi:10.1029/JB095iB08p12527

[18] Holt, "The Active Tectonics of the Eastern Himalaya Syntaxis and Adjoining Regions,” Journal of Geophysical Research, Vol. 96, 1991, pp. 14595-14632.

[19] D. R. Nandy and S. Dasgupta, "Seismotectonic Domains of Northeast India and Adjoining Areas," Physics and Chemistry of the Earth, Vol. 18, No. 1-11, 1991, pp. 371384. doi:10.1016/0079-1946(91)90010-D

[20] G. Pegler and S. Das, “An Enhanced Image of PamirHindu Kusk Seismic Zone from Relocated Earthquake Hypocenters," Geophysics Journal International, Vol. 134, No. 2, 1998, pp. 573-595. doi:10.1046/j.1365-246x.1998.00582.x

[21] D. D. Singh, "Seismotectonics of the Himalaya and Its
Vicinity from Centroid-Moment Tensor (CMT) Solution of Earthquakes,” Journal of Geodynamics, Vol. 30, No. 5, 2000, pp. 507-537. doi:10.1016/S0264-3707(00)00007-7

[22] P. Rao, "Current Deformation of the Himalaya-TibetBurma Seismic Belt: Inferences from Seismic Activity and Strain Rate Analysis,” Journal of Geodynamics, Vol. 36, No. 4, 2003, pp. 485-496. doi:10.1016/S0264-3707(02)00153-9

[23] J. R. Kayal, "Microearthquake Seismology and Seismotectonics of South Asia," Springer, New York, 2008.

[24] Tiwari, "Gravity Anomaly, Lithospheric Structure and Seismicity of Western Himalayan Syntaxis," Journal of Seismology, Vol. 13, No. 3, 2009, pp. 363-370. doi:10.1007/s10950-008-9102-6

[25] Mukhopadhyay, "Seismotectonics at the Terminal Ends of the Himalayan Arc,” Geological Survey of India, Kolkata, 2011.

[26] Wadia Institute of Himalayan Geology, "Syntaxis of the N W Himalayas: Its Rocks, Tectonics and Orogeny,” Records of the Geological Survey of India, Vol. 65, No. 2, 1931, pp. 189-220.

[27] Singh, "Geology and Tectonics of Eastern Syntaxial Bend, Arunachal Himalaya,” Geology, Vol. 4, No. 2, 1993, pp. 149-163.

[28] Acharyya, "Thrust Tectonics and Evolution of Domes and the Syntaxis in Eastern Himalaya," India Journal of $\mathrm{Ne}$ pal Geological Society, Vol. 18, 1998, pp. 1-17.

[29] Valdiya, “Dynamic Himalaya,” Universities Press (India) Limited, Hyderabad, 1998, pp. 1-178.

[30] Nandy, "Geology and Structural Lineament of the Lohit Himalaya (Arunachal Pradesh) and Adjoining Area, a Tectonicinterpretation,” In: Proceeding of Seminar Geodynamin of the Himalayan region, National Geophysical Research Institute, Hyderabad, 1973

[31] J. Thakur, "Some Observation on Deformation, Metamorphism and Tectonic Significance of Rocks of Some Parts of Mishmi Hills, Lohit District, (Arunachal Pradesh)," Himalayan Geology, 1975

[32] Acharya, "Structural Framework and Tectonic Evolution of the Eastern Himalaya,” Himalayan Geology, Vol. 10, 1980, pp. 412-439.

[33] Misra and T. Singh, “Active Faults along the Lohit and Dibang Valleys of Eastern Arunachal Pradesh,” Himalayan Geology, Vol. 24, No. 1, 2003, pp. 83-90.

[34] N. S. Gururajan and B. K. Choudhuri, "Geology and Tectonic History of the Lohit Valley, Eastern Arunachal," Journal of Asian Earth Sciences, Vol. 21, No. 7, 2003, pp. 731-741.

[35] Nakata, "Geomorphic History and Crustal Movement of Himalaya,” Institute of Geography, Tohuku University, Sendai, 1972.

[36] R. S. Yeats, et al., "The Himalayan Frontal Fault System,” Annales Tectonicae, Supplement, Vol. 6, 1992, pp. 85-98.

[37] K. S. Valdiya, "Himalayan Transverse Faults and Folds and Their Parallelism with Subsurface Structures of the Northern Indian Plains,” Tectonophysics, Vol. 32, No. 3-4, 
1976, pp. 353-386. doi:10.1016/0040-1951(76)90069-X

[38] K. S. Valdiya, “Dynamic Himalaya,” Universities Press (India) Ltd., Hyderabad, 1998, pp. 1-178.

[39] T. Nakata, “Active Faults of the Himalaya of Nepal, Tectonics of Western Himalaya,” Special Paper-Geological Society of America, Vol. 232, 1989, pp. 243-264.

[40] J. P. Burg, et al., "The Namche-Barwasyntaxis: Evidence for Exhumation Related to Compressional Crustal Folding,” Journal of Asian Earth Sciences, Vol. 16, No. 2-3, 1997, pp. 239-252. doi:10.1016/S0743-9547(98)00002-6

[41] S. S. Bhakuni, et al., "Structural and Tectonic Studies of Mountain Front of Northeastern Himalaya, Arunachal Pradesh, India: Implication to Active Tectonics," Himalayan Geology (Abstract), Vol. 29, No. 3, 2008.

[42] Z. Chen, et al., "Global Positioning System Measurements from Eastern Tibet and Their Implications for India/Eurasia Intercontinental Deformation," Journal of Geophysical Research, Vol. 105, No. B7, 2000, pp. 16215-16227.

[43] R. W. King, "Geodetic Measurement of Crustal Motion in Southwest China,” Geology, Vol. 25, No. 2, 1997, pp. 179-182.

doi:10.1130/0091-7613(1997)025<0179:GMOCMI>2.3. $\mathrm{CO} ; 2$

[44] W. E. Holt, et al., "Velocity Field in Asia Inferred from Quaternary Fault Slip Rates and Global Positioning System Observations," Journal of Geophysical Research: Solid Earth, Vol. 105, No. B8, 2000, pp. 19185-19209. doi:10.1029/2000JB900045

[45] P. England and P. Molnar, "Active Deformation of Asia: From Kinematics to Dynamics,” Science, Vol. 278, No. 5338, 1997, pp. 647-650. doi:10.1126/science.278.5338.647

[46] G. W. Michel, et al., "Crustal Motion in E- and SE-Asia from GPS Measurements,” Earth Planets Space, Vol. 52,
No. 10, 2000, pp. 713-720.

[47] J. Freymueller, et al., "Global Positioning System Measurements of Indian Plate Motion and Convergence across the Lesser Himalaya," Geophysical Research Letters, Vol. 23, No. 22, 1996, pp. 3107-3110. doi:10.1029/96GL02518

[48] K. M. Larson, et al., "Kinematics of the India-Eurasia Collision Zone from GPS Measurements," Journal of Geophysical Research: Solid Earth, Vol. 104, No. B1, 1999, pp. 1077-1093.

[49] S. Sol, et al., "Geodynamics of the Southeastern Tibetan Plateau from Seismic Anisotropy and Geodesy," The Geological Society of America, Vol. 35, No. 6, 2007, pp. 563-566.

[50] P.-Z. Zhang, "Continous Deformation in the Tibetan Plateau from GPS,” Geology, Vol. 32, No. 9, 2004, p. 809. doi:10.1130/G20554.1

[51] Z. K. Shen, J. N. Lu, M. Wang and R. Bürgmann, “Contemporary Crustal Deformation around the Southeast Borderland of the Tibetan Plateau," Journal of Geophysical Research, Vol. 110, No. B11, 2005, pp. 1-17. doi:10.1029/2004JB003421

[52] S. Jade, et al., "Estimates of Interseismic Deformation in Northeast India from GPS Measurements," Earth and Planetary Science Letters, Vol. 263, No. 3-4, 2007, pp. 221-234. doi:10.1016/j.epsl.2007.08.031

[53] J. F. Dewey, R. M. Shackleton, C. F. Chang and Y. Y. Sun, "The Tectonic Evolution of the Tibetan Plateau," Philosophical Transactions of the Royal Society London A, Vol. 327, No. 1594, 1988, pp. 379-413.

[54] A. Socquet and M. Pubellier, "Cenozoic Deformation in Western Yunnan (China-Myanmar Border)," Journal of Asian Earth Sciences, Vol. 24, No. 4, 2005, pp. 495-515. doi:10.1016/j.jseaes.2004.03.006 